\title{
From model outputs to conservation action: Prioritizing locations for implementing agricultural best management practices in a Midwestern watershed
}

\author{
J.T. Legge, P.J. Doran, M.E. Herbert, J. Asher, G. O’Neil, S. Mysorekar, S. Sowa, and K.R. Hall
}

\begin{abstract}
Many ecologically significant Midwestern rivers are heavily impacted by agriculture yet retain high value for conservation of biodiversity. To address these concerns, watershed managers promote conservation practices (e.g., use of cover crops). Yet taking action to promote implementation of these practices in a cost-effective manner across a watershed is difficult because we rarely know where practices will be most effective, or how much of a benefit will accrue as the result of implementation of a given practice. To improve targeting of conservation practice implementation in locations most beneficial to biodiversity, we propose using a flexible approach assessing fields across a watershed for contributions towards ecological outcomes. We focused on Michigan's Paw Paw River Watershed, where key concerns for biodiversity include reduced infiltration and groundwater recharge that lead to pronounced low and high flow periods, and reduced water quality due to high sediment loads. We used outputs from several existing models to identify and prioritize the agricultural fields where conservation practices will have the greatest reduction in threats to biodiversity, including estimates of the input to groundwater and reduction in sedimentation. We tested the usefulness of our approach using four scenarios for implementation of six practices that vary in terms of the concentration of the practices in areas recommended by the models. Estimates of groundwater recharge under these scenarios were compared to recharge under simulated, "historic" placement scenarios based on USDA Natural Resources Conservation Service (NRCS) data for applied conservation practices in the same watershed. Collectively across the six practices, the prioritized scenarios provided an increase in groundwater recharge of between 23\% and 36\% over the historic scenario. Results for sediment reduction were more variable, but prioritized scenarios suggested a doubling of benefit can be obtained by focusing on agricultural lands predicted to contribute the highest sediment volumes. To maximize the benefits of aggregating practices, we identified subbasins of the watershed for direct outreach to landowners based on a ranking of potential, cumulative downstream conservation benefits and on opportunity factors. As a result of this process, prioritized areas and estimates of groundwater recharge are now informing implementation of conservation practices in the Paw Paw River Watershed, an approach applicable across the region.
\end{abstract}

Key words: conservation practices-groundwater recharge-modeling-quantification of benefits-sedimentation

The outcomes of agricultural conservation practices, while typically evaluated by acres implemented or similar application parameters, can be more adequately judged using quantification of ecological outcomes to provide a more meaningful indication of value and an incentive for efficient use of funding. Like most con-

servation challenges where resources are very limited relative to the scale of impacts, effectively protecting rivers and other natural habitats in agricultural landscapes requires that we prioritize our investments. Many researchers have developed tools and models to help define what aspects of the ecosystem are at risk (Sowa et al. 2007; Esselman et al.
2011) and what agricultural best management practices can help reduce impacts (Mishra et al. 2007; Diebel et al. 2009). However, delivering measurable benefits to sensitive systems requires that we connect theoretical models to relevant conservation outcomes and improve our understanding of how to measure, and produce, conservation success. In the context of implementing agricultural conservation practices, the goal of increasing benefits to ecological systems is constrained by a mismatch in how "success" is measured, in that efforts are typically evaluated by acres of practice implementation. Here we describe a demonstration of our efforts to shift measurements toward quantification of ecological outcomes, which we suggest provides a more meaningful indication of value and an incentive for efficient use of funding.

The USDA Natural Resources Conservation Service (NRCS), in partnership with local soil and water conservation districts, has been assisting farmers and ranchers with voluntary implementation of agricultural conservation practices to address soil, water, and related natural resource concerns for many decades. Various conservation programs authorized through federal (Farm Bill) policy provide financial assistance to producers to implement these conservation practices. Supported by NRCS technical standards, conservation practices have been widely used as a strategy for reducing nonpoint source pollution from farmlands into surface waterways. Some conservation practices, such as conservation tillage, also improve groundwater infiltration, which can reduce the excessive flashiness frequently found in watersheds dominated by agriculture (Schilling and Libra 2003; Swinton et al. 2007; Tomer et al. 2005). Maximizing these benefits is a common goal for watershed managers.

Unfortunately, conservation practices frequently do not attain the desired water-

John T. Legge is a conservation project director, Patrick J. Doran is a director of conservation, and Matthew E. Herbert is an aquatic ecologist with The Nature Conservancy, Lansing, Michigan. Jeremiah Asher is a geographic information system (GIS) project manager, and Glenn O'Neill is a GIS specialist with the Institute for Water Research, Michigan State University, East Lansing, Michigan. Sagar Mysorekar is a GIS manager, Scott Sowa is director of science, and Kim R. Hall is a Great Lakes climate change ecologist with The Nature Conservancy, Lansing, Michigan. 
shed-scale water quality benefits (Tomer and Locke 2011). When combined with an increasing risk that public funding for conservation practices may be reduced, it is critical that we find ways to increase the benefits attained from the practices implemented. Since the magnitude of benefits that accrue from conservation practices varies with the soils, distance to a water body, topography, and crop (Qiu 2003; Gitau et al. 2005), many modeling efforts have developed targeting or optimization systems to identify the most cost-effective set of locations for implementing conservation practices in a given watershed (Richardson and Gatti 1999; Veith et al. 2004; Mishra et al. 2007; Schilling and Wolter 2009). However, optimization systems are often focused on a single optimal solution of preferred locations, making the outcome insufficiently flexible for practical applications where actual implementation is only possible with willing landowners. Another shortcoming of most targeting efforts is that they are focused on individual outcomes (e.g., sediment). These are important first iterations, but ultimately conservation practices are implemented for multiple objectives. Quantification of ecological benefits that would accrue from specific conservation practices on individual parcels would provide a more flexible, realistic, and useful tool, especially to enable scaling incentive payments to match the benefits from specific producers' actions (Wünscher et al. 2008). Quantification could also be used to prioritize lands for receiving financial support for implementing practices, increasing the efficiency in reaching watershed improvement goals. Through quantification of ecological benefits, we can begin to evaluate whether we can effectively prioritize for multiple benefits and still provide significant progress toward each specific type of benefit.

While using tools to optimize benefits to factors such as water quality, it is critical that we recognize that these benefits will be provided across a complex landscape. Some areas provide greater quantifiable conservation benefits than others, and conservation practice placement should reflect not only water quality benefits but also the overarching conservation outcomes. For example, improving water quality upstream from high quality ecosystems, highly valued resources (e.g., fisheries), or water bodies used as drinking water are important societal benefits. Priority areas for maximizing water quality benefits should be juxtaposed with these types of high-value conservation targets.

Southwest Michigan's Paw Paw River Watershed has been identified as important for biodiversity conservation in the Great Lakes Basin (Nature Conservancy 2001). The river is significant for its relatively intact, forested floodplain; diverse headwater communities with large prairie fen and swamp systems, buffered by remnant oak savannas; and the quality of the freshwater community in the main stem of the Paw Paw River and in the East Branch, a headwater tributary (Nature Conservancy 2001). The watershed covers approximately 115,560 ha $(285,557$ ac) with its outlet located at $42^{\circ} 06^{\prime} 47.31^{\prime \prime} \mathrm{N}$, $86^{\circ} 28^{\prime} 19.89^{\prime \prime} \mathrm{W}$ and a total length of approximately $233 \mathrm{~km}$ (145 miles), including major tributaries. According to the 2001 National Land Cover Dataset (NLCD), row crop agriculture covered roughly $39 \%$ of the watershed (Homer et al. 2007). This land use pattern has contributed to sedimentation and changes in the hydrologic regime. The upper and middle sections of the Paw Paw Watershed are dominated by sandy/loamy soil types in hydrologic soil group (HSG) A, which provide the river with moderate to high groundwater inputs. In the lower parts of the watershed, sandy clayloam soils (HSG C soils) predominate, with a lower infiltration rate. Slopes are modest through much of the watershed.

Improving groundwater recharge was identified as a particularly important factor for maintaining the historic hydrologic regime of the Paw Paw due to the naturally high groundwater inputs to the river system (Michigan Department of Environmental Quality 2005) and trends in streamflow that indicate increasing runoff and decreasing groundwater contributions in recent years (Nature Conservancy 2008). Sedimentation was also identified as a key threat to the ecology of the river (Nature Conservancy 2008).

Our objective was to prioritize agricultural lands in the Paw Paw Watershed to determine where to focus targeted outreach that maximizes ecological outcomes from the implementation of USDA conservation practices. Our intent was to develop a flexible system that would highlight differences in the conservation benefit potential across the agricultural landscape, allowing targeted recruitment of high-benefit landowners that could include added financial incentives. We utilized well-established hydrological models to identify the locations likely to return the greatest environmental benefits as measured by groundwater recharge and sediment retention if conservation practices were implemented. We also identified priority subwatersheds based not only upon the concentration of field-scale benefits, but also with consideration to connectivity to the main stem of the river, position in the watershed, and conservation opportunityall which are important variables guiding overall effectiveness of conservation efforts. This is among the first studies to (1) prioritize locations for agricultural conservation practices for multiple ecological benefits, at both the field scale for implementation and the subwatershed scale for conservation planning and outreach, and (2) quantify the differences in ecological benefits among various targeting approaches.

\section{Materials and Methods}

Model and Decision Tool Development. We first used a set of well-established hydrological models to produce information on parameters that would help us identify the locations likely to return the greatest environmental benefits as measured by groundwater recharge and sediment retention if conservation practices were implemented. These parameters included (1) areas at greatest risk of erosion contributing to stream sedimentation, based on High Impact Target (HIT) modeling (Ouyang et al. 2005); (2) potential for improving infiltration (and ultimately contributions to groundwater) by implementing conservation practices, using Soil and Water Assessment Tool (SWAT) simulation modeling; and (3) likelihood of groundwater withdrawal to adversely affect fish communities, using Michigan's Water Withdrawal Assessment Tool (Michigan Department of Environmental Quality 2009) (figure 1). The outputs of three models were generated and merged at the scale of 900 $\mathrm{m}^{2}\left(9,688 \mathrm{ft}^{2}\right)$ grid cells. The resulting values can be combined across the area of an individual farmer's fields (i.e., the units of land that a farmer manages) to prioritize areas for specific conservation practices (those beneficial for increasing groundwater recharge and reducing sedimentation) across the Paw Paw River Watershed.

Our analysis focused on row crop farmland because there are many conservation practice options for improving recharge and reducing sedimentation. While orchards are also prominent in the watershed, their perennial cropping system produces proportionally 


\section{Figure 1}

Conceptual model for identification of the most efficient locations for implementation of conservation practices. We combined models for three factors: susceptibility to additional groundwater withdrawal using Michigan's Water Withdrawal Assessment Tool, groundwater recharge potential using the Soil and Water Assessment tool, and areas at risk of erosion contributing to stream sedimentation using High Impact Targeting. The outputs were combined to produce field-scale priorities. Second, we factored in local conditions to identify priority subwatersheds for implementation using placement within the watershed, conservation opportunity, and main stem connectivity.

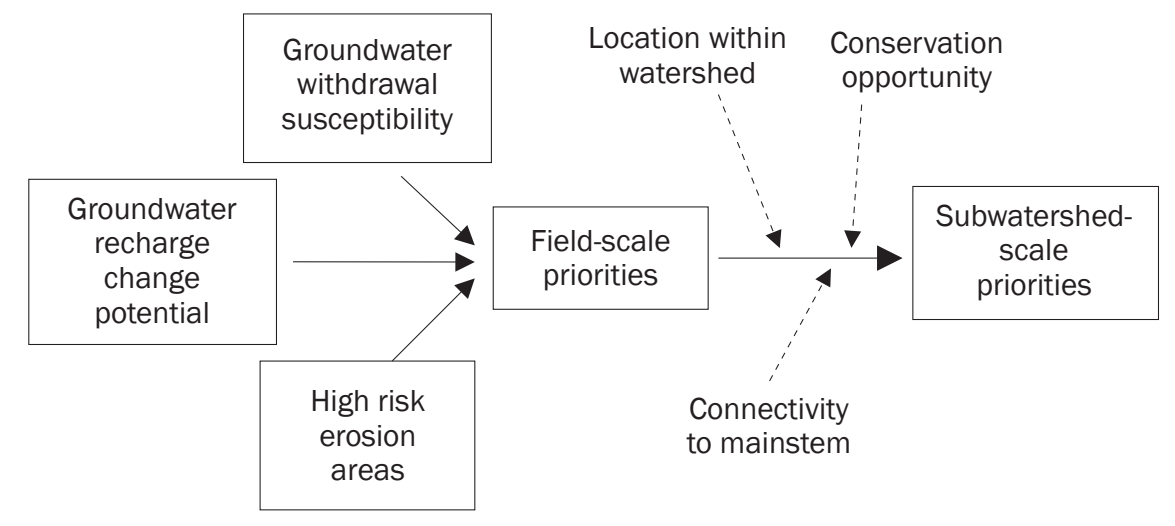

fewer impacts to hydrology and sedimentation, so conservation practices produce fewer benefits. Also, fewer conservation practices for orchards are available for implementation and modeling.

The HIT model was used for estimating sediment delivery. Available for the United States portion of the Great Lakes Basin (O'Neil et al. 2009), HIT is a product of two underlying models: the Revised Universal Soil Loss Equation or RUSLE (Renard et al. 1997), which estimates annual volume of eroded soil, and the Spatially Explicit Delivery Model or SEDMOD (Fraser 1999), which estimates the percentage of soil from any given area that enters a stream system as sediment. We ran each model within a geographic information system (GIS) raster environment, at a $900 \mathrm{~m}^{2}\left(9,688 \mathrm{ft}^{2}\right)$ cell resolution. Outputs from the RUSLE model were calculated based on slope-length relationships derived from United States Geological Survey (USGS) $30 \mathrm{~m}$ (98ft) resolution digital elevation models (DEMs), soil erodibility (K-factor) from the USDA Soil Survey Geographic (SSURGO) database (USDA NRCS 1995), and annual rainfall intensity (R-factor) from the Parameter-elevation Regressions on Independent Slopes Model group at Oregon State University (PRISM Climate Group 2002). These data were combined with a version of the 2001 NLCD (Homer et al. 2007) that was integrated with tillage practice and crop rotations inferred from Conservation Technology Information
Center Crop Residue Management Surveys (CTIC 2000, 2002, 2004) for the study area. Our SEDMOD runs utilized the same DEMs and the USGS High Resolution National Hydrography Dataset to simulate surface water flow and the stream network of the Paw Paw River Watershed. These were combined with clay content information from SSURGO and surface roughness derived from the NLCD to characterize the path and transport of sediments to the stream network. Through combining the RUSLE and SEDMOD outputs, the HIT model identifies those areas at greatest risk of producing eroding sediment that will reach the river or its tributaries. Model efficiency measures of RUSLE-estimated average annual soil loss compared to observed soil loss have ranged between 0.7 and 0.8 (Risse et al. 1993; Rapp 1994; Tiwari et al. 2000). Unlike RUSLE, the SEDMOD component of HIT has not had extensive testing. The most rigorous validation of the accuracy of HIT's output at subfield level resolution (and therefore the most rigorous validation of SEDMOD) was assessed in three Michigan 8-digit hydrologic unit code watersheds with similar geology, soils, and landform to that of the Paw Paw. That analysis determined that HIT is roughly $70 \%$ accurate in identifying sedimentation risk (O’Neil 2010). The validation did not measure actual sedimentation volume; those values depend on the accuracy of RUSLE itself, which is already well-established. The assigned values of annual erosion reaching streams from the $900 \mathrm{~m}^{2}$ units of agricultural land across the watershed varied from more than $1.8 \mathrm{t} \mathrm{ha}^{-1} \mathrm{y}^{-1}\left(0.8 \mathrm{tn} \mathrm{ac}^{-1} \mathrm{yr}^{-1}\right)$ ( $7 \%$ of agricultural land in the watershed), to 0.89 to $1.80 \mathrm{t} \mathrm{ha}^{-1} \mathrm{y}^{-1}\left(0.4\right.$ to $\left.0.8 \mathrm{tn} \mathrm{ac}^{-1} \mathrm{yr}^{-1}\right)$ (11\% of agricultural land), to 0.44 to $0.89 \mathrm{t}$ $\mathrm{ha}^{-1} \mathrm{y}^{-1}$ (0.2 to 0.4 tn ac $\mathrm{yr}^{-1}$ ) (14\% of agricultural land) (figure 2). Remaining cells in agricultural areas contributed less than 0.44 $\mathrm{t} \mathrm{ha}^{-1} \mathrm{y}^{-1}\left(0.2 \mathrm{tn} \mathrm{ac}^{-1} \mathrm{yr}^{-1}\right)$ of sediment. It is important to point out that these estimates are likely below the actual erosion and sediment loading occurring in the Paw Paw because RUSLE only estimates annual sheet erosion and does not quantify erosion from large gullies, stream banks, or wind. However, the relativized estimates of erosion and sediment loading provided by HIT are still very useful for prioritizing conservation actions at the watershed scale.

Infiltration and groundwater recharge were modeled with SWAT (Neitsch et al. 2005). The SWAT model has been widely used to assess infiltration on a watershed scale (Gassman et al. 2005). The SWAT model was used to estimate the hydrologic water balance in the Paw Paw River Watershed under current land cover and then to estimate groundwater recharge for broad soil types under different land management practices. The watershed was divided into subbasins and then subdivided into hydrologic response units representing different combinations of land use/land cover/management, soil type, and weather data. For each unit, a water budget was calculated including daily surface runoff and peak runoff rate. Relationships between soil type, land cover, and water infiltration across modeling units were identified and used to create an estimate of infiltration and groundwater recharge under different soil types (i.e., HSGs) and with different potential land uses and types of agricultural management. Soil maps were created to reflect differences in recharge benefits among soil types with changes in land cover or agricultural management.

The water balance model within SWAT was developed based on the work of two previous studies within the Kalamazoo River Watershed (Safferman et al. 2008). The SWAT model was calibrated on a subbasin level within the Kalamazoo River Watershed using USGS gauge data from seven gauging stations, including the Paw Paw River gauge (USGS gauge \#04102500), to calibrate streamflow between gauging stations. 


\section{Figure 2}

Estimated sediment loading in the Paw Paw River Watershed, Michigan, based on High Impact Targeting.

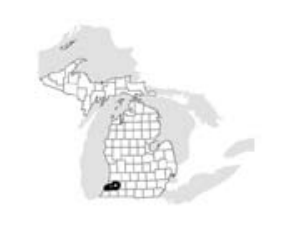

\section{Legend}

maw Paw River

Sediment (tn $\left.\mathrm{ac}^{-1} \mathrm{yr}^{-1}\right)$
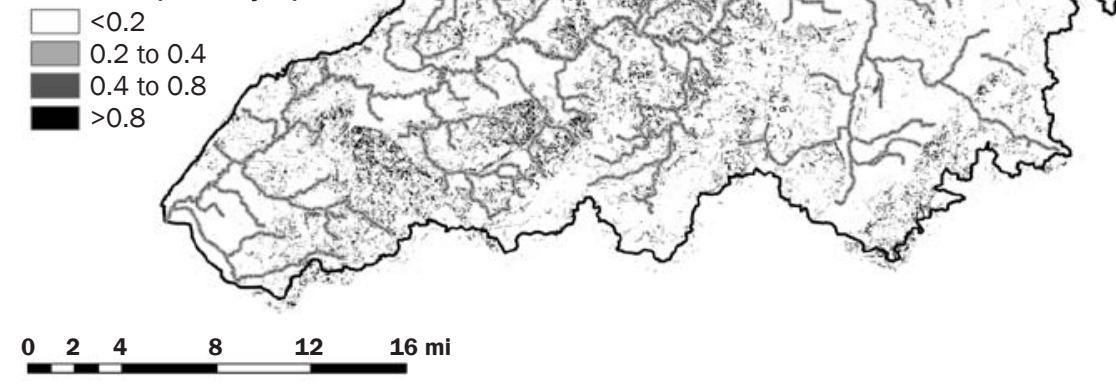

Paw Paw River Watershed. These weather data were averaged across the period of 1971 to 2008. The DEM used to delineate the Paw Paw River Watershed within the SWAT model was from a statewide coverage obtained from the Michigan Center for Geographic Information. The DEM had a spatial resolution of $30 \mathrm{~m}(98 \mathrm{ft})$ and was projected in the Michigan Georef Projection.

As part of the process of estimating groundwater recharge and infiltration from SWAT, data were averaged within the four main HSGs in the watershed. Ranging from the sandiest soils with greatest percolation to the most hydric soils, these HSGs are labeled A-D, A, B, and C. The outputs from this component of our prioritization indicate that groundwater recharge benefits from conservation practices varied with soil type. Soils in HSG C have the lowest infiltration rates and respond with the highest groundwater recharge increases under reduced tillage and no-till. But when cover crops are added to tillage practices, HSG A soils with high infiltration rates produce the greatest recharge increases (table 1). The complexity of the interactions between soil type and practices can hinder the effective use of such information by local practitioners. So, to facilitate use of these data by local practitioners, the SWAT data was placed into an online groundwater recharge "calculator" (Asher et al. 2010). The SWAT modeling results were first used to create a look-up table comparing the difference in infiltration between potential land uses and management regimes across soil types for all agricultural lands in the Paw Paw River Watershed. The look-up table was then linked with soil data through an online map interface, allowing users to draw a polygon for a parcel of land and identify the change in land use (e.g., from conventional tillage agriculture to reduced tillage agriculture). This calculator allows the user to estimate changes in groundwater infiltration in gallons per acre, on the fly, from potential changes in land management.

Finally, the third set of model inputs that informed our prioritization came from the WWAT model, which was used for assessing sensitivity to groundwater withdrawal. Developed by the Institute for Water Research at Michigan State University, MDNR, USGS, and Michigan Department of Environmental Quality, WWAT is a tool that estimates the amount of flow of a river or stream that could be reduced (e.g., through and solar radiation were obtained through the Michigan Climate Office for the longterm National Weather Service station at Bloomingdale, Michigan, just north of the 
groundwater pumping) before the species composition and abundance of fish in the river would be adversely impacted (Reeves et al. 2009). The tool provides a water availability map developed from estimated index flow for the lowest summer flow month via analysis of long-term streamflow gauging stations and regression modeling from ungauged stream sites (Hamilton et al. 2008), and fish response curves related to catchment area, baseflow yield, and July mean temperature. The underlying model uses habitat suitability information from Michigan for over 40 fish species to predict assemblage structure and characteristic assemblages in river segments under a range of base flow reductions. River segments statewide were classified into 11 types related to catchment size and July river temperature, and fish assemblages were predicted for each combination. Model runs developed for individual fish species at representative segments of the river types were used to develop curves describing the response of each fish assemblage to flow reduction. The resulting WWAT model provides a framework for evaluating impacts of flow withdrawals on fish communities across Michigan (Zorn et al. 2008). The model was used to identify those subbasins in which a diversion of 568 $\mathrm{L} \mathrm{min}^{-1}$ (150 gal $\mathrm{min}^{-1}$ ) of baseflow (either via groundwater pumping or surface water withdrawal) would be likely to result in the degradation of fish community species composition. Available baseflow at or below $568 \mathrm{~L} \mathrm{~min}^{-1}$ is relatively small and could be exceeded with the installation of one typical high capacity water withdrawal. In analyzing sensitivity to groundwater withdrawal, the WWAT model identified eight subbasins that are at greatest risk, in which 91 to 568 $\mathrm{L} \min ^{-1}$ (24 to $150 \mathrm{gal} \mathrm{min}^{-1}$ ) of baseflow is available for pumping before potentially causing an adverse impact (figure 3). Seven of these subbasins are quite small, representing only $3.4 \%$ of the agricultural land in the Paw Paw Watershed. The eighth at-risk subbasin, Mill Creek, is one of the larger $(4,500$ ha $[11,100 \mathrm{ac}])$ and more significant agricultural portions of the watershed, with $9.7 \%$ of the watershed's agricultural land. Remaining subbasins are currently at relatively low risk from additional groundwater pumping.

Prioritization Process and Approach: Field-Scale Prioritization. To identify priority locations where conservation practice implementation could optimize ground-

\section{Figure 3}

Risk of subbasins of the Paw Paw River Watershed, Michigan, to additional groundwater withdrawals based on the state's Water Withdrawal Assessment Tool.

\section{Legend}

\section{Available groundwater before \\ adverse resource impact (gal $\mathrm{min}^{-1}$ )}

24 to 150 (highest risk)

150 to 500

500 to 1,580

1,580 to 3,700

3,700 to 9,895 (Lowest river)

? Paw Paw River

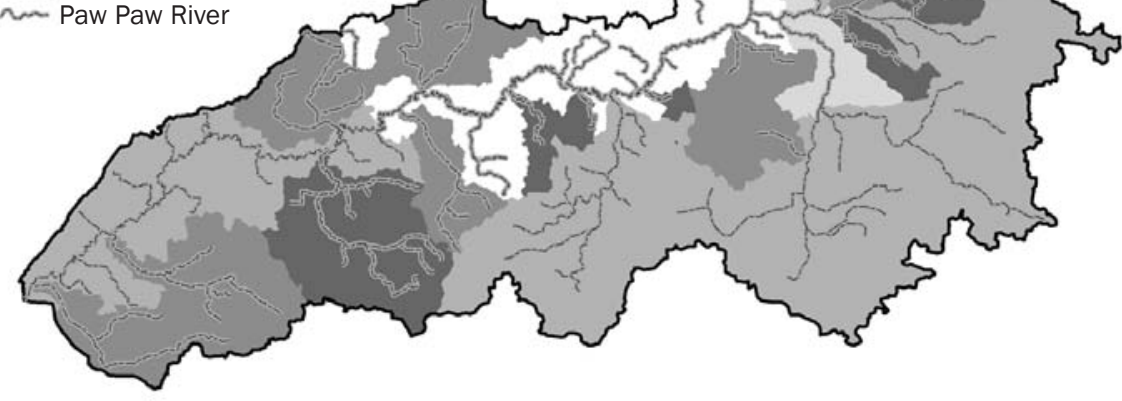

$\begin{array}{lll}0 & 2 & 4\end{array}$ 8

12 $16 \mathrm{mi}$

water recharge, minimize sediment loading, and buffer against groundwater withdrawal impacts, we combined data from the three models (HIT, SWAT, and WWAT) and mapped the resulting calculation, termed priority value, including only lands in the watershed with active row crop agriculture. We assigned the highest value to agricultural lands where HIT estimated sediment loading as high, where the WWAT indicated a low amount of available groundwater as baseflow to streams, and on soils that would provide the highest groundwater recharge modeled in SWAT.The three input layers were reclassified into numeric classes from 1 to 4 at natural breaks, with 4 considered to have the highest score. Sedimentation risk was assigned the highest weight because the HIT modeling provides the most site-specific information. We gave the lowest weighting to groundwater availability (modeled by WWAT) because Michigan law already requires use of this model in groundwater permitting. Soil Water Assessment Tool modeling demonstrated that HSG played a strong influence on the benefits of tillage practices, so relatively moist HSG C soils were considered and mapped separately from drier A soils. This weighting scheme was derived based on local knowledge of the watershed and desired ecological outcomes. Our analysis of the prioritization outcomes was designed to test the effectiveness of our approach.
The following calculations were used for C soils:

Priority value $=($ Sedimentation-risk priority $\times 0.8)+($ Groundwater availability priority $\times 0.2) \times($ Soil priority $[\mathrm{A}=0, \mathrm{~B}=0.5, \mathrm{C}=$ $1, \mathrm{D}=0]) \times($ Land cover priority [Row crop lands $=1$, All other lands $=0]$ ).

The following calculations were used for A soils:

Priority value $=($ Sedimentation-risk priority $\times 0.8)+($ Groundwater availability priority $\times 0.2) \times($ Soil priority $[\mathrm{A}=1, \mathrm{~B}=0.5, \mathrm{C}=$ $0, \mathrm{D}=0]) \times($ Land cover priority [Row crop lands $=1$, All other lands $=0]$ ).

The range in priority value, mapped at the $900 \mathrm{~m}^{2}\left(9,688 \mathrm{ft}^{2}\right)$ scale (matching the HIT modeling), differentiates among units of land by the extent to which they are at risk for producing sediment, their potential for providing additional groundwater recharge under conservation practices, and the existing level of stress of groundwater resources. With a higher priority value, we expect that conservation practices on that land will provide greater benefits in terms of reduced sedimentation and increased groundwater recharge.

Subwatershed-Scale Prioritization. In addition to the field-scale prioritization, we also wanted to prioritize at the subwatershed 
scale so that we could focus outreach within subsections of the watershed, rather than at high-ranking fields across the entire geographic area. Two units of land may have the same priority value, but one may produce greater benefits for the overall watershed based on its placement in the watershed (e.g., upstream areas will have a greater impact than those further downstream). Concentrating landowner outreach and resulting conservation practices in a smaller part of the watershed also allows us to concentrate BMPs, which should increase our ability to detect improvements. This concentration of effort will also improve the efficiency of time spent working with landowners. In effect, we are adding an additional set of subbasin-scale factors to the modeling results, with the goal of converting these results to a more actionable subset of prioritized lands that can be used to inform focused outreach efforts and subsequent implementation of conservation practices and produce the greatest impacts on conservation targets. We scored the subbasins based on the following four criteria:

(a) Watershed position: Improvements in water quality and quantity within a watershed will provide the most benefits to a particular river system if they are implemented nearer to the headwaters of the watershed. Scoring: 1 to 4 points, with 1 point for the subbasins of the first third of the main stem towards the outlet, 2 points for the subbasins of the middle third of the main stem, 3 points for the subbasins along the upper third of the main stem, and 4 points for the headwaters subbasins.

(b) Connectivity to the main stem: Reduction in sedimentation and hydrologic restoration due to increased groundwater recharge will have less downstream benefit in subbasins that are partially or wholly cut off from the main stem by reservoirs and/or dams. Scoring: 2 points for subbasins cut off by reservoirs and 4 points for other subbasins.

(c) Concentration of priority locations: Although all subbasins contain areas that were identified as high in priority value through the modeling processes, high value locations are more concentrated in some areas. Concentration was calculated based on the proportion of a subbasin's area with a priority value of 3 or more. Scoring: 1 to 4 points based on natural breaks in the proportion of impact in a subbasin, with subbasins having the greatest concentration of high priority value areas receiving 4 points.

(d) Opportunity: The Van Buren Conservation District has a long history of working with Paw Paw Watershed farmers to encourage implementation of conservation practices. Van Buren Conservation District staff informally evaluated the results of the analysis and identified areas of significant opportunity based on three factors: (i) perceived interest of farmers not already enrolled in conservation programs, (ii) complementarity with conservation outreach efforts by the Van Buren Drain Commissioner, and (iii) potential for largest impact based on land ownership pattern and existing practices. Scoring: 4 points if identified as having opportunity for factors i, ii, and iii; 3 points if identified as having opportunity for 2 of the 3 factors; 2 points if identified as having opportunity for 1 of the 3 factors; and 1 point if not identified as having any opportunity factors.

The scores for the four criteria were summed for each subbasin to develop an overall score that would be used to guide outreach and enrollment.

Assessing Likely Efficiencies and Benefits of Our Approach. Following our work developing the prioritization components, we examined the level of increase in ecological benefits suggested by our modeling tools if we were to successfully implement conservation practices at the prioritized locations in the Paw Paw River Watershed. We compared estimates of groundwater recharge benefits and sedimentation rates for three placement scenarios: (1) historic locations, (2) random locations, and (3) four sets of priority locations. All scenarios were based upon the type, size, and frequency of practices implemented in the watershed from 1999 to 2009 (hereafter referred to as historic data) (USDA NRCS 2010). Conservation practices were limited to those that were applicable to groundwater recharge and sedimentation benefits and that were implemented in at least 25 locations during the historic conservation practice period. These practices included: (1) Conservation Cover (perennial vegetative cover, NRCS Practice Code \#327); (2) Cover Crop (\#340); (3) Residue and Tillage Management, Mulch Till (\#345); (4) Residue and Tillage Management, No-Till/
Strip Till/Direct Seed (\#329); (5) Residue Management, Mulch Till (\#329B); and (6) Residue Management, No-Till/Strip Till (\#329A) (USDA NRCS 2012b).

To represent practices across the watershed, we used the NRCS historic data on conservation practices which consist of a point location representing a specific practice type, with the area of the practice included in the accompanying data. To convert these lists of point locations to a spatial representation, we created circular buffers around each point location to create polygons and sized the buffer to match the actual area of practice implementation. The resulting spatial data represented our historic scenario and gave us a way of quantifying potential benefits using spatial data outputs from various steps in our prioritization process.

To develop the random scenario for placement of practices within agricultural lands across the watershed, we also used information from the historic practice data, but changed their locations. To do this, we generated a set of random points for each conservation practice using the random function from Geospatial Modeling Environment (Beyer 2012) that was equal to the number of locations where each practice was implemented historically. For example, if conservation cover was historically implemented at 158 locations, then 158 random points were created to represent the random scenario for conservation cover. Points for each practice were buffered to create polygons matching the average size of that practice from the historic dataset. The random scenario was repeated three times so that variance could be calculated and the scenario could be statistically compared.

Similarly, to determine conservation practice locations for our four priority scenarios, we built from the information contained in the historic agricultural placement data, but constrained the placement of practices to a set of random locations with concentrations of high priority values. Given that our prioritization was at the level of a 900 $\mathrm{m}^{2}\left(9,688 \mathrm{ft}^{2}\right)$ pixel, we aggregated the pixels to reflect the scale at which practices would be applied. To achieve this aggregation, we applied the neighborhood window function in ArcGIS to the priority value dataset to create clear distinctions between areas of high, medium, and low priority value. For example, if a high value cell was surrounded by low and medium value cells, it received 
a mean value based on its neighboring cells. This approach increased the likelihood that high priority value cells bordered mainly by other high priority value cells were selected. For neighborhood window we used a circular area around each pixel with a radius set to produce an area equal to the average size of that practice from the historic dataset. We produced four sets of prioritized areas to include locations for all of the six practices taken from within the top 5\%,10\%,20\%, and $30 \%$ of priority value areas, as weighted by priority value of neighboring pixels. These scenarios were designated as the $5 \%, 10 \%$, $20 \%$, and $30 \%$ priority scenarios, respectively. The process of selecting locations for each priority scenario (5\% up to $30 \%$ ) was repeated three times so that variance could be calculated, which allowed calculations of benefits derived from each scenario to be statistically compared with other scenarios.

To calculate groundwater recharge benefits, the spatial data layers representing historic, random, and the four priority scenario locations for the six conservation practices were overlaid with HSGs. For each conservation practice type and distribution scenario (historic, random, and multiple levels of priority area), groundwater recharge rates-as determined for the watershed by the SWAT modeling described above-were used to calculate the change in recharge from conventional tillage to each conservation practice. Switchgrass (Panicum virgatum) was used as the land cover to calculate recharge benefits for Conservation Cover because this best represents the typical land cover used for this practice in the watershed (J. Foster, personal communication, March 1, 2011). The groundwater recharge rates were calculated for each soil type within each practice application and then combined for each conservation practice type for each scenario. Portions of the watershed contained "null" hydrologic soil values (e.g., water or areas outside of the watershed). Approximately $5 \%$ of buffers (polygons) contained a small percentage of area with these null values. In these cases, we calculated the sedimentation or recharge contribution by assigning the "no data" areas to soil types in the same proportion as was found in the polygon. This allowed us to hold the total area for each practice constant across all scenarios.

To calculate benefits from reduced sedimentation, the average sedimentation susceptibility for each scenario was calculated from HIT results using the zonal statistics function from the GIS application. The set of polygons for each of the scenarios was overlaid onto the HIT sedimentation layer to calculate "mean" sediment value for each polygon.

For each conservation practice, we tested for differences among the historic, random, and the four priority scenarios using analysis of variance and, with significance, tested for specific differences among scenarios using Tukey's honestly significant difference test (Kirk 1968).

\section{Results and Discussion}

Prioritization Process and Approach: FieldScale Prioritization. The prioritization generated through combining the various models resulted in two analyses, one emphasizing the importance of targeting HSG A soils and the other emphasizing HSG C soils due to their differential influence on groundwater recharge with different practices. Each $900 \mathrm{~m}^{2}\left(9,688 \mathrm{ft}^{2}\right)$ cell received a priority value score ranging from 0 to 4 , with 4 as the highest possible score indicating those places where investments in conservation practices would yield the largest ecological outcomes (figure 4). For the HSG A, the high priority value indicates those areas where a combination of conservation tillage and cover crop practices would produce the greatest groundwater recharge benefits. For the HSG $\mathrm{C}$, conservation tillage alone produces the greatest recharge benefits. In both cases, the HIT modeling had the greatest impact on the scoring because the HIT output is differentiated at the $900 \mathrm{~m}^{2}$ level. In contrast, SWAT produces the same output across a soil type, and WWAT produces the same emphasis across a subbasin.

Combined across the HSGs, the prioritization identified 157 ha (388 ac) with the highest priority value of 4 , or $0.35 \%$ of the agricultural land found in the Paw Paw Watershed. There were 2,009 ha (4,964 ac) or $4.48 \%$ of agricultural land with a priority value of $3 ; 4,017$ ha $(9,926 \mathrm{ac})$ or $8.96 \%$ with a priority value 2 ; and 21,628 ha $(5,3444 \mathrm{ac})$ or $48.21 \%$ with a priority value of 1 . The remaining row crop land of the watershed, $38 \%$, scored less than 1 . This distribution of priority value scores across the watershed shows the concentration of the highest values (priority value from 2 to 4 ) concentrated on a small part of the agricultural land, only $13.79 \%$ of the total cropland.
Subwatershed-Scale

Prioritization. Scoring of subbasins differentiated the 15 subbasins; with scores ranging from 7 to 14 points (figure 5). Three of the top four subbasins were selected for testing direct outreach to accelerate implementation of conservation practices, including Brandywine Creek (14 points), South Branch (13 points), and Mill Creek (12 points).

Outreach and implementation began as a three-year program in the three top subbasins in spring of 2010, through a partnership of the Van Buren Conservation District and The Nature Conservancy with funding from the Coca-Cola Foundation. As of January 2012, targeted outreach has brought an additional 853 ha $(2,108 \mathrm{ac})$ of Paw Paw Watershed crop land into conservation practices, of which $75 \%$ of these lands come from the three top subbasins where outreach has been focused. New conservation practices include cover crops, conservation tillage, no-till, buffer strips, and conservation cover.

Assessing Likely Efficiencies and Benefits of Prioritizing Approach. The comparison between our four priority scenarios and both historic and random scenarios in the watershed shows a significant benefit from concentrating implementation of conservation practices in locations with high priority value, in most cases. Groundwater recharge was significantly higher within each priority scenario (top 5\%,10\%,20\%, and 30\%) in comparison with historic and random scenarios (figure 6). For groundwater recharge, five of the six practices in the historic scenario performed no better than the random scenario, and for conservation cover, the random scenario performed significantly better. Priority scenarios show an increase in recharge as the percent level of high priority value land increases for most practices, as would be expected, with the exception of Residue and Tillage Management, Mulch Till. Cover Crops have a negative impact on groundwater recharge for all samples, but the impact decreases with increasing percent level of high priority value land.

In comparison to the historic scenario, our four priority scenarios estimated a large cumulative improvement in groundwater recharge for the three most beneficial practices (Residue and Tillage Management, No-Till/Strip Till/Direct Seed; Conservation Cover; and Residue Management, No-Till/Strip Till). The estimates ranged from 1.647 billion $\mathrm{L} \mathrm{y}^{-1}(0.44$ 


\section{Figure 4}

Priority agricultural lands for implementing conservation practices in order to increase groundwater recharge and reduce sedimentation, differentiated for hydrologic soil groups A (equation 2) and C (equation 1).

\section{Legend}

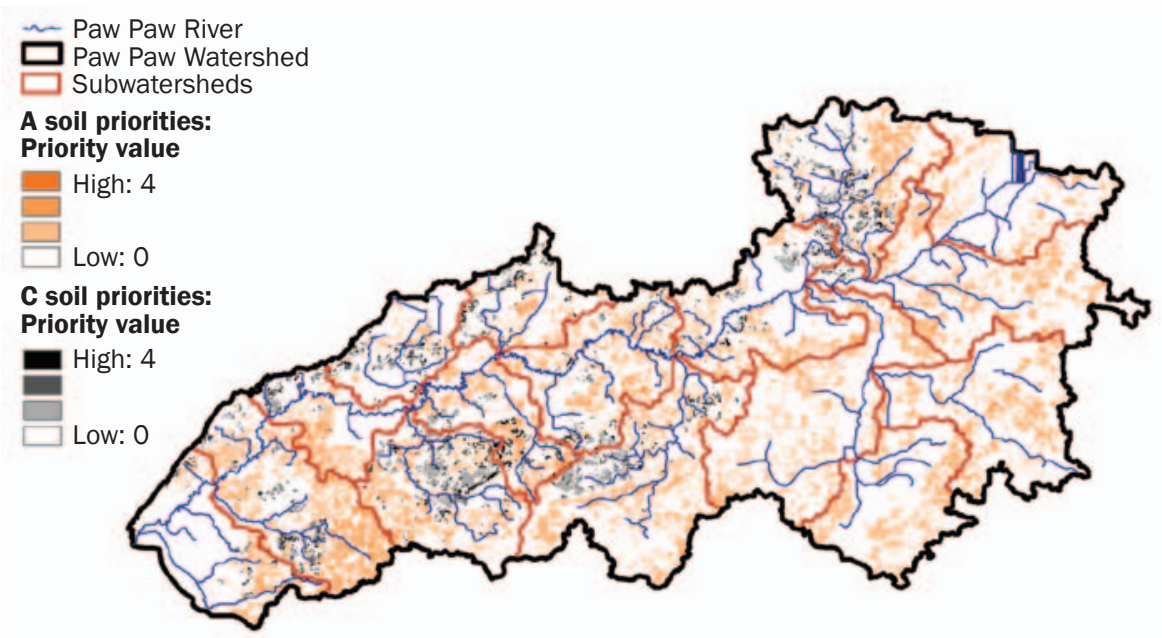

\begin{tabular}{lrrrrr}
0 & 2 & 4 & 8 & 12 & 16 \\
\hline
\end{tabular}

\section{Figure 5}

Subwatershed prioritization. Scores were given for watershed position ( 1 to 4 points); connectivity to the river main stem (either 2 or 4 points); concentration of acres judged "Moderate," "High," or "Highest" priority in figure 4 ( 1 to 4 points); and qualitative assessment of opportunity based on interest of farmers, complementarity with other programs, and potential for impact based on land ownership factors ( 1 to 4 points).

\section{Legend}

\section{Cumulative prioritization score}

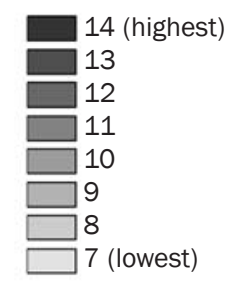

\section{Priority subwatersheds:}

1 - Brandywine Creek

2 - South Branch

3 - Mill Creek

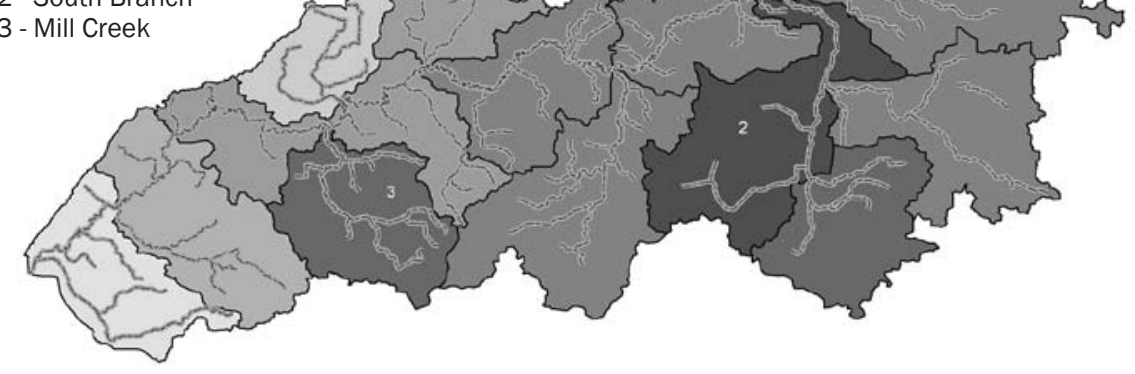

01.53 $6 \quad 9$ $12 \mathrm{mi}$ billion gal $\mathrm{yr}^{-1}$ ) for the three practices at the $30 \%$ priority scenario to 2.625 billion

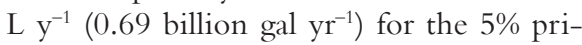
ority scenario. (The estimates were derived by adding the average recharge for the three practices for each of the three simulations and taking the difference between the priority scenario amount and the historic scenario amount.) Even for the other three practices, the four priority scenarios had an estimated, combined improvement in groundwater recharge of between 707 million and 1.023 billion $\mathrm{L} \mathrm{y}^{-1}$ (187 million and 0.27 billion gal $\mathrm{yr}^{-1}$ ).

Collectively across the six practices, the placement of practices in the high priority value locations provides an increase in groundwater recharge of between $23 \%$ and $36 \%$ over the historic scenario (table 2). To achieve these additional recharge benefits without prioritizing locations would have cost an estimated additional US $\$ 466,118$ to US\$722,146. This cost difference was calculated by first estimating the historic investment in practices by multiplying the estimated NRCS per-acre payment for each practice (USDA NRCS 2012a) by the number of acres for each practice in the historic scenario. Using the modeled gross recharge amounts, we estimated the cost that was paid under the historic scenario for each liter of increased groundwater recharge. Each priority scenario provided an estimate of the number of liters of increased recharge for the six practices. For each priority scenario, we multiplied this increased number of liters by the cost-per-liter rate under the historic scenario. This calculation provided an estimate of what it would have cost to provide the groundwater recharge achieved under each priority scenario if practices were distributed without prioritization, as in the historic scenario.

Comparisons of potential benefits from reductions in sedimentation were more mixed (figure 7). The historic scenario performed at least as well as the random scenario for treating the locations with highest risk of causing sedimentation for all practices and significantly better for the Conservation Cover practice. For five of the six practices, all four priority scenarios had greater potential benefit than the historic and random scenarios, but not all of these were statistically significant. In comparison to the historic scenario, our four priority scenarios had a cumulative improvement in focusing on high-risk locations for sedimentation that ranged from $124 \%$ to $231 \%$ for the three strongest prac- 


\section{Figure 6}

Performance of prioritized locations for increased groundwater recharge under six common conservation practices, compared to performance of historic and randomized areas.

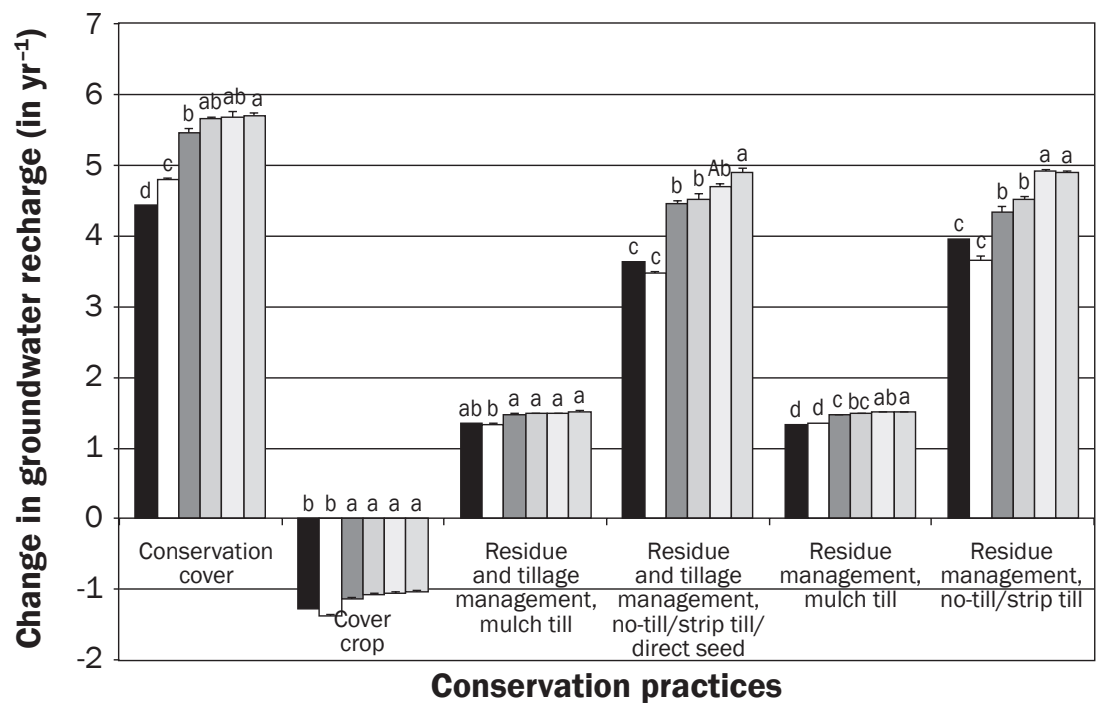

\section{Legend}

口 Historic $\square$ Randomized $\square<30 \% \quad \square<20 \% \quad \square<10 \% \quad \square<5 \%$

Notes: Prioritized locations were considered in four samples constrained to the top 30\%, 20\%, $10 \%$, and $5 \%$ of priority land. Columns within a conservation practice type are designated with letters a through d indicating significant difference, such that two columns with the same letter are not significantly different in their change in groundwater recharge.

tices (Residue and Tillage Management, Mulch Till; Residue Management No-Till/ Strip Till; and Residue Management, Mulch Till). Even for the other three practices, the four priority scenarios had an improvement of $1 \%$ to $49 \%$ per year.

This work illustrates two major points about ecological benefits from agricultural conservation practices. First, our results suggest that historic application of conservation practices by the NRCS has had remarkable outcomes. From 1999 to 2009, six types of practices in the Paw Paw River Watershed increased groundwater recharge by nearly one billion L (0.26 billion gal) annually (figure 6) and focused largely on lands most at risk for eroding sediment to the river, preventing the deposition of many tons of sediment (figure 7). The outcomes in preventing sedimentation are particularly notable with the historic scenario significantly outperforming the random scenario in conservation cover. This is likely due to the concentration of some NRCS programs on highly erodible soils and the local knowledge of conservation district staff that appears to have directed practices to many locations with high priority value.

Second, our work nevertheless provides a powerful approach to improve placement of conservation practices by strategically locating them based on quantitative ecological benefits. The prioritized approach can help maximize the ecological benefits derived from scarce dollars available for USDA programs promoting conservation practices. Our analysis demonstrates that targeting the location of conservation practices is significantly more efficient in producing environmental benefits than historic approaches. For groundwater, targeting the six practices at the minimum level (the $30 \%$ priority scenario) still resulted in over 2.35 billion additional $\mathrm{L}$ ( 0.62 billion additional gal) of groundwater recharge over the historic scenario, a 23\% increase. Achieving these benefits without targeting would require additional conservation expenditures estimated at US $\$ 466,118$. Estimated volume of sediment reduction is not available, but priority scenarios showed more than a $100 \%$ improvement in the average sedimentation susceptibility of lands identified for three of the six practices. Thus, the prioritized scenarios did a better job overall than the historic scenario of locating those practices on agricultural lands at risk for producing the highest sediment volumes. Since agricultural programs have focused especially on erosive soil loss, it is logical that the historic scenario produced better results for sedimentation than groundwater recharge. It is also noteworthy that prioritization can make such a significant improvement even for results on sedimentation.

\section{Summary and Conclusions}

Across the United States, USDA conservation programs authorized by the Farm Bill are by far the greatest source for incentivizing producers to implement conservation practices with the goal of improving environmental conditions. It is widely recognized that meeting reasonable water quality, quantity, and related biological goals in agricultural watersheds, like the Paw Paw River Watershed, will require more efficient and strategic use of these program dollars (Maresch et al. 2008). Targeting practices to those locations that provide relatively high ecological benefits per unit cost is the most logical strategy for achieving these increased efficiencies. There are some targeting mechanisms in place that have improved the performance of conservation programs, like the Conservation Reserve Program and the Environmental Quality Incentives Program, but much more could be done (Hansen and Hellerstein 2006). Recognizing this need, The Nature Conservancy has been working with the Van Buren Conservation District (Michigan), the NRCS in Van Buren County, Michigan, and Coca-Cola Refreshments (CCR), to develop a multiscale approach for generating ecological goals and targeting conservation practices to more efficiently achieve those goals across the Paw Paw River Watershed.

We agree with Veith et al. (2004) that optimization scenarios are important and useful for setting ecological goals at watershed scales; however, they provide little assistance in strategic, field-scale targeting of conservation programs and practices. The lack of detailed, field-level information on both the cost and benefits of conservation practices is a key factor hindering such targeting (Hansen and Hellerstein 2006). More specifically, still needed are data, models, and decision tools that provide resource managers and farmers with the ability to work cooperatively to assess costs and benefits across a range of realistic options and to foster flexible targeting of practices that are suited to the real-world decision process surrounding farmer participation. We believe our approach in the Paw Paw River Watershed provides managers and farmers with this 
Table 2

Ten-year increase in estimated groundwater recharge for two priority scenarios in comparison to the historic scenario (1999 to 2009).

\begin{tabular}{|c|c|c|c|c|c|c|c|c|}
\hline Practice & $\begin{array}{l}\text { Total acres } \\
\text { treated per } \\
\text { scenario (ac) }\end{array}$ & $\begin{array}{l}\text { Estimated } \\
\text { per-acre } \\
\text { cost (US\$) }\end{array}$ & Scenario & $\begin{array}{l}\text { Historic } \\
\text { investment } \\
\text { (US\$) }\end{array}$ & $\begin{array}{l}\text { Gross } \\
\text { recharge } \\
\text { (L) }\end{array}$ & $\begin{array}{l}\text { Recharge } \\
\text { increase } \\
\text { (L) }\end{array}$ & $\begin{array}{l}\text { Increase in } \\
\text { recharge } \\
(\%)\end{array}$ & $\begin{array}{l}\text { Additional cos } \\
\text { for increased } \\
\text { recharge under } \\
\text { historic scenario } \\
\text { (US\$) }\end{array}$ \\
\hline \multirow[t]{3}{*}{ Conservation cover } & 562.8 & 28 & Historic & 157,584 & $2,570,036,033$ & - & - & - \\
\hline & & & $30 \%$ & & $3,158,273,277$ & $588,237,244$ & 23 & 36,068 \\
\hline & & & $5 \%$ & & $3,298,025,826$ & $727,989,793$ & 28 & 44,637 \\
\hline \multirow[t]{3}{*}{ Cover crop } & $1,984.7$ & 53 & Historic & $1,051,891$ & $-2,607,927,529$ & - & - & - \\
\hline & & & $30 \%$ & & $-2,302,224,713$ & $305,702,816$ & 12 & 123,303 \\
\hline & & & $5 \%$ & & $-2,105,149,623$ & $502,777,906$ & 19 & 202,792 \\
\hline $\begin{array}{l}\text { Residue and tillage } \\
\text { management, mulch } \\
\text { till }\end{array}$ & 782.7 & 12 & Historic & 93,924 & $1,092,773,842$ & - & - & - \\
\hline \multirow{2}{*}{$\begin{array}{l}\text { Residue and tillage } \\
\text { management, no-till/ } \\
\text { strip till/direct seed }\end{array}$} & & & $30 \%$ & & $4,095,822,990$ & $759,253,165$ & 23 & 56,847 \\
\hline & & & $5 \%$ & & $4,494,133,033$ & $1,157,563,208$ & 35 & 86,669 \\
\hline \multirow{3}{*}{$\begin{array}{l}\text { Residue management, } \\
\text { mulch till }\end{array}$} & $1,986.7$ & 12 & Historic & 238,404 & $2,712,829,400$ & - & - & - \\
\hline & & & $30 \%$ & & $3,020,277,798$ & $307,448,398$ & 11 & 27,019 \\
\hline & & & $5 \%$ & & $3,103,881,764$ & $391,052,364$ & 14 & 34,366 \\
\hline \multirow{3}{*}{$\begin{array}{l}\text { Residue management, } \\
\text { no-till/strip till }\end{array}$} & 763.3 & 28 & Historic & 231,724 & $3,108,533,025$ & - & & \\
\hline & & & $30 \%$ & & $3,408,353,775$ & $299,820,750$ & 10 & 22,350 \\
\hline & & & $5 \%$ & & $3,847,809,977$ & $739,276,951$ & 24 & 55,109 \\
\hline
\end{tabular}

Notes: Dollar figures in the far right column indicate the cost of providing the additional recharge benefits accrued under priority scenarios at the cost per liter provided under the historic scenario. The historic investment is derived from Natural Resources Conservation Service per-acre costs for each practice multiplied by the number of acres receiving the practice in the watershed from 1999 to 2009 (USDA NRCS 2012a).

flexibility needed to assess options in terms of both placement and type of practices.

Our approach and suite of tools certainly provide direct support to managers for the targeting of conservation practices. However, our approach also indirectly facilitates targeting by both educating farmers and making them directly involved in the decision making process. Numerous studies in the 1980s aimed to identify factors that led some farmers to invest in conservation while others did not. These studies revealed that farmers that understood the linkages between conservation practices and environmental benefits were more likely to participate and also invest more, all other factors being equal (Ervin and Ervin 1982; Norris and Batie 1987; Gould et al. 1989). Farmers consider several factors when deciding whether to participate in conservation programs, including crop production of the site, contract length, practice type and maintenance, payment rate, and environmental benefits, if that information is available (Hansen and Hellerstein 2006). Our groundwater calculator allows farmers to actually assess options for several of these factors. Because of the success of this decision tool, The Nature Conservancy is now working on similar field-scale tools for sediments and nutrients.

Our approach has had multiple direct benefits toward increasing conservation efforts in the Paw Paw River Watershed. While the historic application of conservation practices to the agricultural landscape has resulted in tremendous ecological outcomes, we can achieve even more ecological benefit at an equivalent cost through prioritizing agricultural lands where the greatest ecological benefits will be produced. Calculation of ecological benefits provides a highly valuable measure of our success in addition to programmatic measures, such as the number of acres treated with a conservation practice or the number of contracts processed. We believe that the outcomes of USDA cost-share and incentive funds could be greatly enhanced by incorporating this approach. This would save limited financial resources and achieve the greatest ecosystem benefits from conservation practices applied in agricultural landscapes. Furthermore, our analyses demonstrate that targeting need not be rigid. We can achieve significantly greater benefits by focusing on the top 30\% of sites, not just the top 5\%. Finally, we demonstrate that while the outputs of models like SWAT 


\section{Figure 7}

Performance of the four priority scenarios for targeting agricultural lands likely to cause sedimentation under six common conservation practices, compared to performance of historic and random scenarios.

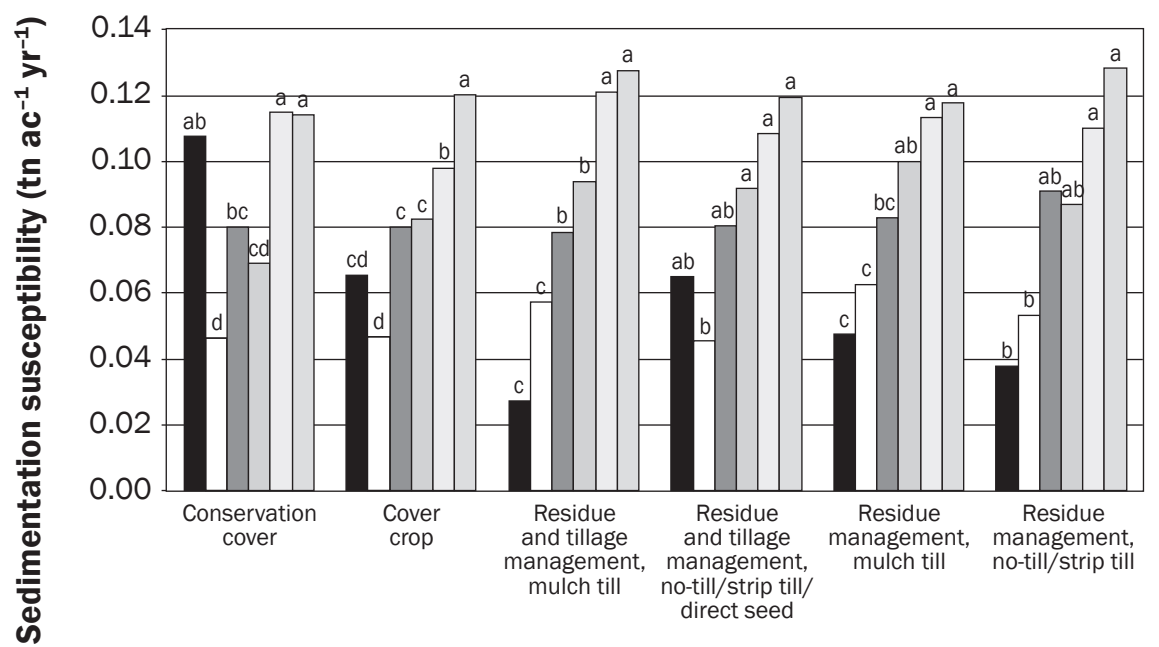

Conservation practices

\section{Legend}

口 Historic $\quad \square$ Randomized $\square<30 \% \quad \square<20 \% \quad \square<10 \% \quad \square<5 \%$

Notes: Prioritized locations were considered in four scenarios constrained to the top $30 \%, 20 \%$, $10 \%$, and $5 \%$ of priority land. Columns within a conservation practice type are designated with letters a through d indicating significant difference, such that two columns with the same letter are not significantly different in their targeting of areas producing high amounts of sediment. are important tools, they prove most useful as a guide to conservation efforts when combined with additional knowledge of ecological and social concerns.

As a result of these benefits, The Nature Conservancy is working with partners to expand this approach to other ecologically important watersheds within the Great Lakes region and to other types of ecological outcomes (e.g., sediment reduction, habitat creation, and carbon sequestration). Such efforts are focused on improving and expanding the underlying data, models, and decision tools. We believe our approach would work equally well in watersheds nationwide where row crop agriculture is a dominant land use.

Finally, our approach and underlying tools can also be used to foster new and innovative approaches to conservation in agricultural landscapes. For example, CCR, a subsidiary of The Coca-Cola Company, operates a Minute Maid bottling plant in the Paw Paw Watershed. The Coca-Cola Company is pursuing a goal of water neutrality in its global operations, defined as mitigating potential impacts of its use of water in production through on-site water conservation and support of off-site watershed improve- ments. Based on this analysis, The Coca-Cola Foundation and CCR have provided support for targeted outreach to recruit landowners identified in our prioritization process for enrollment in USDA-funded cost-share programs to implement conservation practices. The analysis, combined with the field-scale groundwater recharge calculator tool, allows CCR to correlate recharge benefits with practices initiated through their support. The program has an initial goal that would result in improvement to groundwater recharge projected at 134 million L (35 million gal). While working closely with NRCS staff administering the USDA programs, the outreach technician is able to target and recruit landowners whose conservation practice implementation will accrue the greatest ecological benefits to the watershed. This has added welcome capacity to the local NRCS conservation staff, while focusing on a specific, crucial segment of the local farming community.

\section{Acknowledgements}

This study was supported by the Coca-Cola Foundation, the USDA Natural Resources Conservation Service Conservation Effects Assessment Project (Agreement \#687482-11-501), the Americana Foundation, the Partnership for Conservation Science and Economics of The Nature Conservancy (TNC) - Michigan Chapter, the Frederick S. Upton Foundation, and Florence Upjohn Orosz, Martha Upjohn, Amy E. Upjohn, and Bradley E.Vandenberg.

We thank William Northcott of Michigan State University, East Lansing, Michigan, who conducted the SWAT analysis. We thank our local partners for this project, including the Van Buren Conservation District and the Natural Resources Conservation Service in Van Buren County, Michigan. We are grateful to David DeGeus, sustainable agriculture lead, TNC, Otley, Iowa; Joe Fargione, lead scientist, TNC, Minneapolis, Minnesota; Jon Fisher, spatial scientist, TNC, Arlington, Virgina; Peter Kareiva, chief scientist, TNC, Seattle, Washington; Bob Lalasz, director of science communication, TNC, Arlington, Virginia; Jon Radtke, water resources manager, Coca-Cola Refreshments, Atlanta, Georgia; Charlie Rewa, Conservation Effects Assessment Project wildlife component coordinator, USDA Natural Resources Conservation Service, Beltsville, Maryland; and Rena Stricker, ecologist, Watershed Sustainability LLC, Atlanta, Georgia, for their reviews and improvements to earlier versions of this manuscript. Layla Cole, Great Lakes research specialist, TNC, Lansing, Michigan, assisted in the data preparation for the practice comparison analysis. Lara Rienks, conservation coordinator, TNC, Comstock Park, Michigan, and Lauren Bailey, project coordinator, TNC, Lansing, Michigan, provided copyediting and formatting.

\section{References}

Asher, J., G. O'Neil, and B. Northcott. 2010. Paw Paw Watershed Groundwater Recharge Calculator. East Lansing, MI: Michigan State University, Institute for Water Research. http://35.9.116.206/tnc/map.asp.

Beyer,H.L. 2012. Generate Random Points. Spatial Ecology, LLC. http://www.spatialecology.com/gme/genrandompnts.htm. CTIC (Conservation Technology Information Center). 2000. National Crop Residue Management Survey.West Lafayette, IN: Conservation Technology Information Center.

CTIC. 2002. National Crop Residue Management Survey. West Lafayette, IN: Conservation Technology Information Center.

CTIC. 2004. National Crop Residue Management Survey. West Lafayette, IN: Conservation Technology Information Center. Diebel, M.W., J.T. Maxted, D.M. Robertson, S. Han, and M.J. Vander Zanden. 2009. Landscape planning for agricultural nonpoint source pollution reduction III: Assessing phosphorus and sediment reduction potential. Environmental Management 43:69-83.

Ervin, C.A., and D.E. Ervin, 1982. Factors affecting the use of soil conservation practices: Hypotheses, evidence, and policy implications. Land Economics 58(3):277-292.

Esselman, P.C., D.M. Infante, L. Wang, D. Wu, A.R. Cooper, and W.W. Taylor. 2011. An index of cumulative disturbance to river fish habitats of the conterminous United States from landscape anthropogenic activities. Ecological Restoration 29:133-151. 
Fraser, R. 1999. SEDMOD - A GIS based delivery model for diffuse pollutants. PhD dissertation. New Haven, $\mathrm{CN}$ : Yale University, Department of Forestry and Environmental Studies.

Gassman, P.W., M.R. Reyes, C.H. Green, and J.G. Arnold. 2005. SWAT peer-reviewed literature: A review. In Proceedings of the 3rd International SWAT Conference, Zurich, Switzerland, July 11-15, 2005. Temple, TX: USDA Agricultural Research Service.

Gitau, M.W., W.J. Gburek, and A.R. Jarrett. 2005. A tool for estimating best management practice effectiveness for phosphorus pollution control. Journal of Soil and Water Conservation 60:1-10.

Gould,B.W.,W.E.Saupe, and R.M.Klemme. 1989.Conservation tillage:The role of farm and operator characteristics and the perception of soil erosion. Land Economics 65:167-82.

Hamilton, D.A., R.C. Sorrell, and D.J. Holtschlag. 2008. A regression model for computing index flows describing the median flow for the summer month of lowest flow in Michigan: US Geological Survey Scientific Investigations Report 2008-5096, 43p.

Hansen, L.T., and D. Hellerstein. 2006. Better Targeting, Better Outcomes. Economic Brief 34099. Washington, DC: USDA, Economic Research Service.

Homer, C., J.Dewitz, J. Fry, M. Coan, N. Hossain, C. Larson, N. Herold,A.McKerrow,J.N.VanDriel, and J.Wickham. 2007. Completion of the 2001 National Land Cover Database for the conterminous United States. Photogrammetric Engineering and Remote Sensing 73(4):337-341.

Kirk, R.E. 1968. Procedures for the Behavioural Sciences. Belmont, CA: Brooks/Cole.

Maresch, W., M.R. Walbridge, and D. Kugler. 2008. Enhancing conservation on agricultural landscapes: A new direction for the Conservation Effects Assessment Project. Journal of Soil and Water Conservation 63:198A-203A, doi:10.2489/jswc.63.6.198A.

Michigan Department of Environmental Quality. 2005. Public Act 148: Groundwater Inventory and Map Project. Executive Summary. Lansing, MI: Michigan Department of Environmental Quality. http://gwmap. rsgis.msu.edu/Exec_Summ_Final_081805_LoRes.pdf.

Michigan Department of Environmental Quality. 2009. Michigan Water Withdrawal Assessment Tool. Lansing, MI: Michigan Department of Environmental Quality. http://www.miwwat.org/Intro.pdf.

Mishra, A., S. Kar, and V.P. Singh. 2007. Prioritizing structural management by quantifying the effect of land use and land cover on watershed runoff and sediment yield. Water Resources Management 21:1899-1913

Nature Conservancy. 2001. Aquatic ecoregional planning in the US Portion of the Great Lakes Watershed. Chicago, IL:The Nature Conservancy, Great Lakes Program.

Nature Conservancy. 2008. Paw Paw River Watershed Conservation Area Plan. Lansing, MI: The Nature Conservancy.

Neff, B.P., S.M. Day, A.R. Piggott, and L.M. Fuller. 2005. Base Flow in the Great Lakes Basin: US Geological
Survey Scientific Investigations Report 2005-5217. Reston,VA: US Geological Survey.

Neitsch, S.L., J.G. Arnold, J.R. Kiniry, K.W. King, and J.R. Williams. 2005. Soil and Water Assessment Tool (SWAT) Theoretical Documentation. BRC Report 02-05.Temple, TX: Blackland Research Center, Texas Agricultural Experiment Station.

Norris, P.E., and S.S. Batie, 1987. Virginia farmers' soil conservation decisions: An application of Tobit analysis. Southern Journal of Agricultural Economics 19:79-90.

O'Neil, G. 2010. Conservation Innovation Grant final report, Impact Targeting: Applying conservation tools to the worst areas for maximum sediment/nutrient reductions. http://www.hydra.iwr.msu.edu/iwr/cv/proposals/ publications/documents/2009/CIG-FinalReport.pdf.

O'Neil, G., Y. Shi, and J. Asher. 2009. HIT (High Impact Targeting): A tool for optimizing sedimentation reduction efforts in the Great Lakes Basin. Lansing, MI: Michigan State University, Institute for Water Research. www.iwr.msu.edu/hit2.

Ouyang, D., J. Bartholic, and J. Selegean. 2005. Assessing sediment loading from agricultural croplands in the Great Lakes Basin. The Journal of American Science 1(2):14-21.

PRISM (Parameter-elevation Regressions on Independent Slopes Model) Climate Group. 2002. Corvallis, OR Oregon State University. http://prism.oregonstate.edu.

Qiu, Z. 2003.A VSA-based strategy for placing conservation buffers in agricultural watersheds. Environmental Management 32:299-311.

Rapp, J.F. 1994. Error assessment of the Revised Universal Soil Loss Equation using natural runoff plot data. Master's thesis. Tucson, AZ: School of Renewable Natural Resources, University of Arizona.

Reeves, H.W., D.A. Hamilton, P.W. Seelbach, and A.J. Asher. 2009, Ground-water-withdrawal component of the Michigan water-withdrawal screening tool: US Geological Survey Scientific Investigations Report 2009-5003. Reston,VA: US Geological Survey.

Renard, K., G. Foster, G. Weesies, D. McCool, and D. Yoder 1997. Predicting soil erosion by water: A guide to conservation planning with the revised universal soil loss equation (RUSLE). USDA, Agricultural Handbook 703. Washington, DC: USDA Agricultural Research Service.

Richardson, M.S., and R.C. Gatti. 1999. Prioritizing wetland restoration activity within a Wisconsin watershed using GIS modeling. Journal of Soil and Water Conservation 54:537-542.

Risse, L.M., M.A. Nearing, A.D. Nicks, and J.M. Laflen. 1993 Error assessment in the Universal Soil Loss Equation. Soil Science Society of America Journal 57:825-833. Safferman, S., S. Miller, B. Northcott, D. Baas, and G. O'Neil, 2008. Evaluation of SWAT and HIT Models in the Kalamazoo River Watershed, Michigan 103B Final Report. East Lansing, MI: Michigan State University.

Schilling, K.E., and R.D. Libra. 2003. Increased baseflow in Iowa over the second half of the 20th century. Journal of the American Water Resources Association 39:851-860
Schilling, K.E., and C.F. Wolter. 2009. Modeling nitratenitrogen load reduction strategies for the Des Moines River, Iowa using SWAT. Environmental Management 44:671-682.

Sowa, S.P., G. Annis, M.E. Morey, and D.D. Diamond 2007. A gap analysis and comprehensive conservation strategy for riverine ecosystems of Missouri. Ecological Monographs 77:301-334.

Swinton, S.M., F. Lupi, G.P. Robertson, and S.K. Hamilton. 2007. Ecosystem services and agriculture: Cultivating agricultural ecosystems for diverse benefits. Ecological Economics 64:245-252

Tiwari, A.K., L.M. Risse, and M.A. Nearing. 2000 Evaluation of WEPP and its comparison with USLE and RUSLE. Transactions of the American Society of Agricultural Engineers 43(5):1129-1135.

Tomer, M.D., and M.A. Locke. 2011. The challenge of documenting water quality benefits of conservation practices: A review of USDA-ARS's conservation effects assessment project watershed studies. Water Science and Technology 64:300-310.

Tomer, M.D.,D.W.Meek, and L.A.Kramer.2005.Agricultural practices influence flow regimes of headwater streams in western Iowa. Journal of Environmental Quality 34:1547-1558.

USDA NRCS (USDA Natural Resources Conservation Service). 1995. Soil Survey Geographic (SSURGO) Data Base: Data Use Information. Fort Worth, TX: National Cartography and GIS Center.

USDA NRCS. 2010. National Conservation Practice (NCP) database. Washington, DC: USDA Natural Resources Conservation Service.

USDA NRCS. 2012a. Field Office Technical Guide Washington, DC: USDA Natural Resources Conservation Service. http://efotg.sc.egov.usda.gov// efotg_locator.aspx.

USDA NRCS. 2012b. National Conservation Practice Standards. Washington, DC: USDA Natural Resources Conservation Service. http://www.nrcs.usda.gov/wps/ portal/nrcs/main/national/technical/alphabetical/ncps.

USDA NRCS. 2012c. Soil Data Mart. Washington, DC USDA Natural Resources Conservation Service. http:// soildatamart.nrcs.usda.gov.

Veith, T.L., M.L. Wolfe, and C.D. Heatwole. 2004. Costeffective BMP placement: Optimization versus targeting. Transactions of the American Society of Agricultural Engineers 47(5):1585-1594.

Wünscher,T., S. Engel, and S. Wunder. 2008. Spatial targeting of payments for environmental services: A tool for boosting conservation benefits. Ecological Economics 65:822-833.

Zorn, T.G., P.W. Seelbach, E.S. Rutherford, T C. Wills, S.-T. Cheng, and M.J. Wiley. 2008. A regional-scale habitat suitability model to assess the effects of flow reduction on fish assemblages in Michigan streams. Michigan Department of Natural Resources, Fisheries Research Report 2089.Ann Arbor, MI: Michigan Department of Natural Resources. 